CONF-95085)-2

UCRL-JC-120308

PREPRINT

\title{
A Refuelable Zinc/Air Battery for Fleet Electric Vehicle Propulsion
}

\author{
J. F. Cooper \\ D. Fleming \\ D. Hargrove \\ R. Koopman \\ K. Peterman
}

This paper was prepared for submittal to the 1995 SAE Future Transportation Technology

Conference and Exposition

Costa Mesa, CA

August 7-10, 1995

April 20, 1995

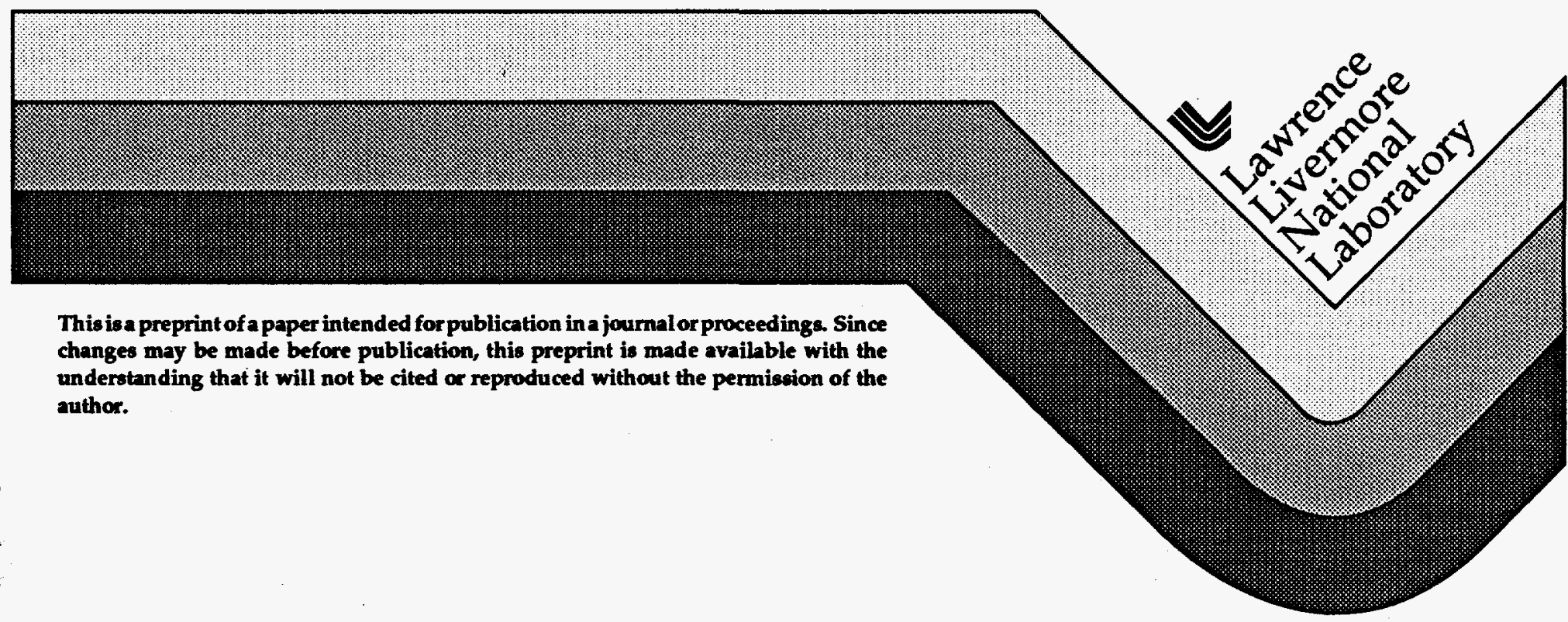




\section{DISCLAIMER}

This document was prepared as an account of work sponsored by an agency of the United States Government. Neither the United States Government nor the University of California nor any of their employees, makes any warranty, express or implied, or assumes any legal liability or responsibility for the accuracy, completeness, or usefulness of any information, apparatus, product, or process disclosed, or represents that its use would not infringe privately owned rights. Reference herein to any specific commercial product, process, or service by trade name, trademark, manufacturer, or otherwise, does not necessarily constitute or imply its endorsement, recommendation, or favoring by the United States Government or the University of California. The views and opinions of authors expressed herein do not necessarily state or reflect those of the United States Government or the University of California, and shall not be used for advertising or product endorsement purposes. 


\section{DISCLAIMER}

Portions of this document may be illegible in electronic image products. Images are produced from the best available original document. 
Paper Submitted to the 1995 SAE Future Transportation Technology Conference and Exposition

Costa Mesa CA; August 7-10, 1995

Manuscript 95-FTT-32 Session FTT-15

\title{
A Refuelable Zinc/Air Battery for Fleet Electric Vehicle Propulsion John F. Cooper, Dennis Fleming, Douglas Hargrove, Ronald Koopman and Keith Peterman Lawrence Livermore National Laboratory, L-369 • Livermore CA 94550
}

\begin{abstract}
We report the development and on-vehicle testing of an engineering prototype zinc/air battery. The battery is refueled by periodic exchange of spent electrolyte for zinc particles entrained in fresh electrolyte. The technology is intended to provide a capability for nearly continuous vehicle operation, using the fleet's home base for $\mathbf{1 0}$ minute refuelings and zinc recycling instead of commercial infrastructure. In the battery, the zinc fuel particles are stored in hoppers, from which they are gravity fed into individual cells and completely consumed during discharge. A six-celled (7V) engineering prototype battery was combined with a $6 \mathrm{~V}$ lead/acid battery to form a parallel hybrid unit, which was tested in series with the $216 \mathrm{~V}$ battery of an electric shuttle bus over a 75 mile circuit. The battery has an energy density of $140 \mathrm{Wh} / \mathrm{kg}$ and a mass density of $1.5 \mathrm{~kg} / \mathrm{L}$. Cost, energy efficiency, and alternative hybrid configurations are discussed.
\end{abstract}

\section{INTRODUCTION}

The use of electric storage batteries to power commercial and industrial fleet vehicles has a number of attractive features. The fleet's home base facilities and personnel constitute a preexisting infrastructure for vehicle maintenance, battery recharging and technical support. Missions are often repetitive (or at least predictable), and daily usage can be high enough to allow rapid write-off of the generally high initial investment in electric propulsion. Examples of fleet electric vehicles include electric shuttle and transit busses, commercial delivery and passenger vans, enclosure-operated vehicles such as fork-lift trucks and mall shuttles, and specialty applications ranging from aircraft service vehicles to silent military equipment. To undertake long-duration missions (e.g., lasting a substantial fraction of the day), the batteries might be periodically exchanged, "opportunity" charged, or extended with heat engines. However, these approaches increase cost and servicing complexity while restricting mission flexibility.

Alternatively, the batteries may be mechanically recharged by a rapid exchange of fresh reactants for reaction products--while the products are externally recycled. In recent years, a number of efforts have been made to develop high energy density batteries which are refuelable or reconstructable [1-5], as a means of combining long range with a capability for nearly continuous use through periodic refueling.

The objectives of the battery development work reported here are: (1) develop an engineering prototype based upon our self-feeding cell invention [1]; (2) determine energy and power characteristics; (3) demonstrate rapid refueling; and (4) show that the self-feeding cell operates under representative road vibrations and accelerations. 


\section{TECHNICAL APPROACH}

System. Our approach is shown schematically in Figure 1. The battery consumes zinc metal and atmospheric oxygen, and produces a reaction product consisting of a liquid suspension of zinc oxides and potassium zincate in an alkaline electrolyte:

$$
\mathrm{Zn}+1 / 2 \mathrm{O}_{2} \text { (air) }+\mathrm{KOH}=\mathrm{KZnOOH}_{\mathrm{aq}}
$$

Refueling is accomplished by replacing the spent electrolyte with fresh electrolyte and zinc pellets. The spent electrolyte is reprocessed in equipment at the fleet's home base to recover zinc-depleted electrolyte and zinc fines, which are pressed into uniform $1 \mathrm{~mm}$ pellets. The cost of the recovery unit is small compared with the cost of the battery because it operates continuously and hence at a lower power level than the battery. In addition, it lacks the expensive air electrode of the zinc/air battery, which accounts for half the estimated battery cost of $\$ 50 / \mathrm{kW}$.

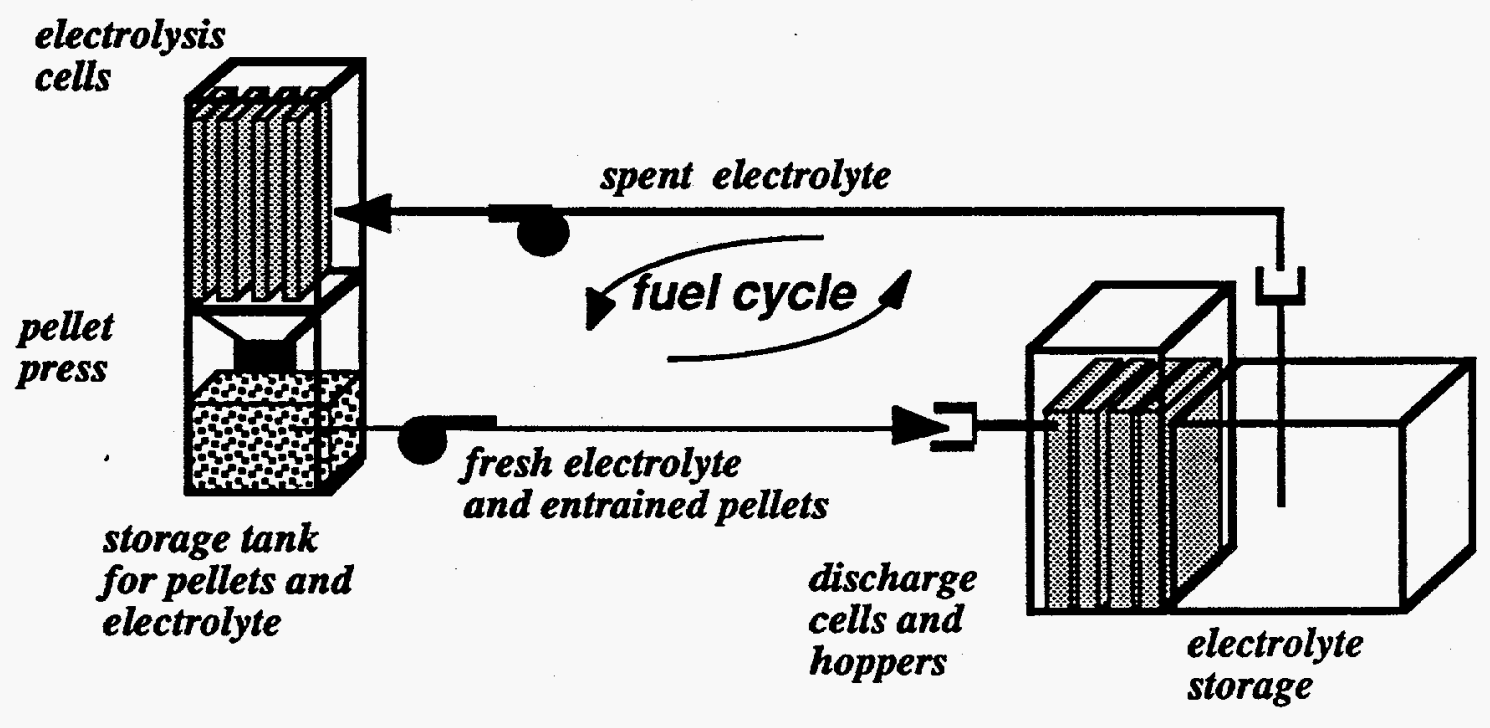

ZINC RECYCLE UNIT

ZINC/AIR BATTERY

Figure 1. The battery consists of a stack of bipolar cells which are gravity fed with zinc particles from overlying hoppers, and an electrolyte storage tank. Refueling exchanges spent electrolyte for fresh electrolyte with entrained zinc particles. Electrolysis equipment recycles zinc and fresh electrolyte from the spent electrolyte.

Self-feeding cell. During discharge, zinc pellets fall continuously from the overlying hopper into a narrow ( $<3 \mathrm{~mm}$ ) opening at the top of each cell (Figure 2). Because the cell gap is only a few times larger than the particles, the particles do not close pack--even when subjected to strong vibrations. Rather, particle bridging and voids develop, which gives the bed an artificially low packing density of about $40 \%$. Electrolyte flows upward through the cell and hopper to remove heat and reaction products. The expanded bed offers little resistance to electrolyte flow. The wedge-shape of the cell allows dissolving zinc particles to fall into an increasingly narrow gap to maintain the gap/particle size ratio $(<5)$ needed for bridging. The losses from air and electrolyte pumping and shunt currents sum to about $1 \%$ of gross power [7].

Refueling. The $1 \mathrm{~mm}$ particles are too heavy to be easily levitated into a uniform slurry by flowing electrolyte in the battery. Rather, the particles are pushed along the base of a horizontal fill tube common to a multicell stack by the impulse of flowing electrolyte. The 
particles fall through slots $(6 \times 16 \mathrm{~mm})$ leading into the hoppers. Because the anodes may be shorted through particles in the fill tube, it is necessary to shut off the air supply to the cells during filling and to continue electrolyte flow after filling to remove excess zinc and electrolyte from the fill tubes.

Zinc recovery and recycle Using a combined electrochemical and mechanical process, zinc pellets were produced from recycled battery reaction product. Zinc was recovered from spent battery reaction products by deposition onto a nickel substrate under conditions of current density and flow resulting in a porous deposit called "mossy zinc." This deposit is approximately 15-20\% metal. It does not adhere to the electrode but detaches under its own weight to collect at the bottom of the electrolysis cell. The deposit is pressed into $1 \mathrm{~mm} \times 1 \mathrm{~mm}$ cylindrical pellets of $60 \%$ density using a simple pin and die press. Details of the process will be reported in a later publication. Experimental work reported here uses commercial 0.5- or $1 \mathrm{~mm}$ cut wire as fuel.

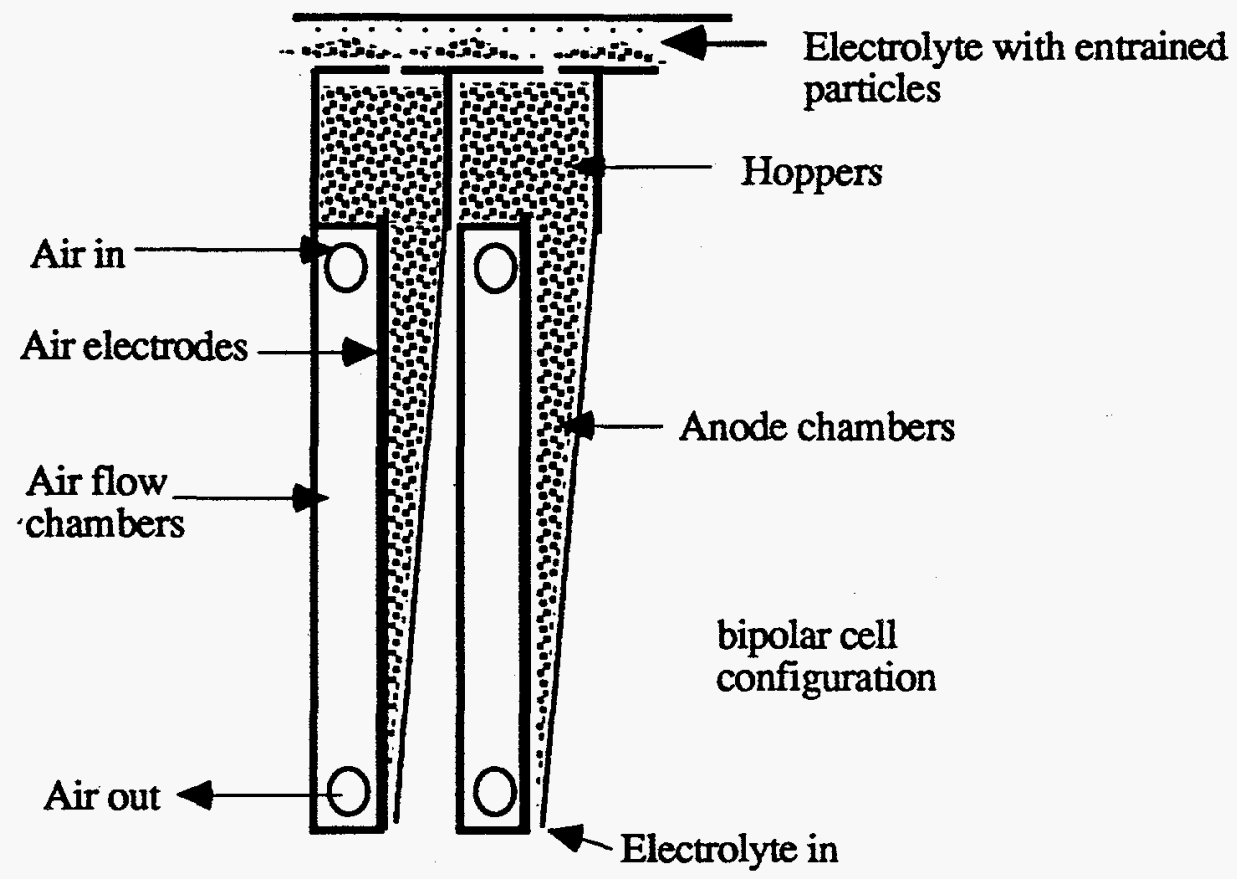

Figure 2. Zinc pellets or particles are stored in hoppers above individual cells, and are gravity fed into the cells. Packing and clogging in the bed are prevented by the formation of bridges and voids, allowing electrolyte to circulate freely and with low hydraulic resistance.

\section{TECHNICAL RESULTS}

Battery components. Our electrochemical cell is comprised of two components: (1) A plastic frame contains the hopper, channels for air and electrolyte circulation, seals and a porous separator [9]. (2) A bipolar plate supports both anode and cathode [8] and is provided with feedthroughs to electrically connect the adjacent cells. Up to 12 cells can be combined with the electrolyte storage tank (Figure 3 ). The number of cells determines power, the size of the storage tank determines energy content.

The plastic frame is shown in Figure 4. The electrode area $\left(250 \mathrm{~cm}^{2}\right)$ and hopper volume $\left(150 \mathrm{~cm}^{3}\right)$ are chosen to yield a peak power of about $125 \mathrm{~W}$ and a nominal energy of up to 525 Wh (at $1.2 \mathrm{~kW} / \mathrm{m}^{2}$ ) -- a combination anticipated for the shuttle bus application requiring a 5-10 hour rate and modest power. (Electrode area, hopper volume and storage tank volume can be varied independently to match vehicle power and energy requirements.) The long electrolyte 
channels between cells reduce shunt losses for a 12 cell stack to below $0.5 \%$ of gross power. Electrolyte flows upwards at a phase velocity of $1 \mathrm{~cm} / \mathrm{s}$, while air flows downwards at 4 times the rate required by stoichiometry for $6 \mathrm{kA} / \mathrm{m}^{2}$-the maximum cell current density.

The bipolar plate supports a metal basket attached to the anode surface and a ribbed frame on the cathode surface to hold the air electrode. The plate was fabricated from electronic circuit board ( 62 mil; both sides copper-clad; glass-filled epoxy resin).

Refueling. Refueling of a 12-cell stack of $250 \mathrm{~cm}^{2}$ cells was developed before discharge tests. The particles were fed into the assembled stack (Figure 3) through two internal $2.5 \mathrm{~cm}$ diameter tubes, driven by combine flow of $4.5 \mathrm{~L} / \mathrm{min}$ with a total pressure drop of $2 \mathrm{kPa}$ across the stack. As shown in Figure 5, the cells filled sequentially at a rate of 4 cells per minute. Three parallel sets of three 12-cell stacks connected in hydraulic series can thus be refueled in under 10 minutes and will contain $56.7 \mathrm{kWh}$ of deliverable energy [6].

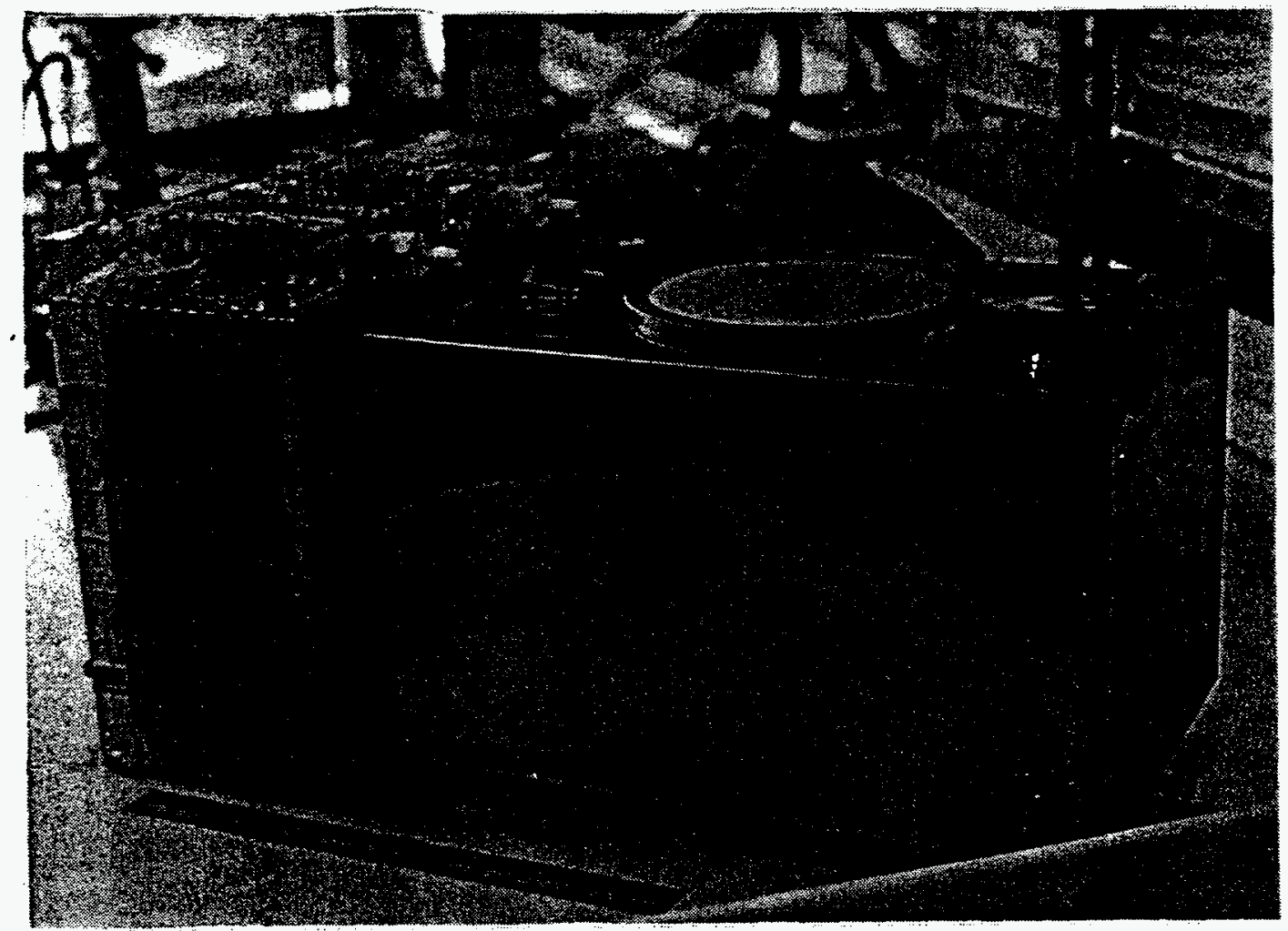

Figure 3. The twelve-cell stack and electrolyte tank is shown here, assembled for refueling tests. Cooling fins (Aavid Engineering, Inc. NH) were added to the storage tank prior to discharge tests on 3- and 6-celled units. 


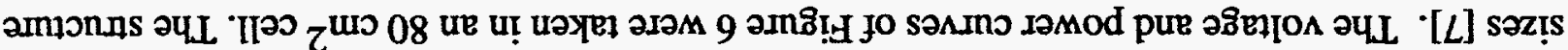

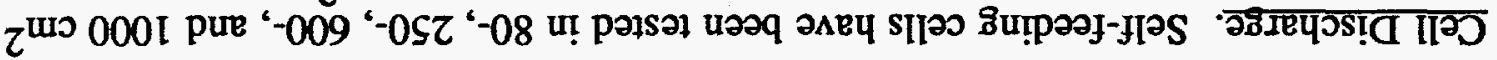

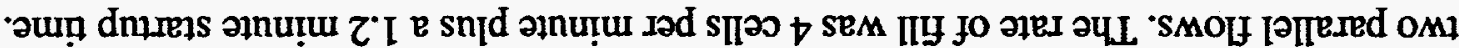

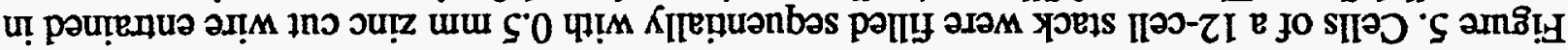
səqunu

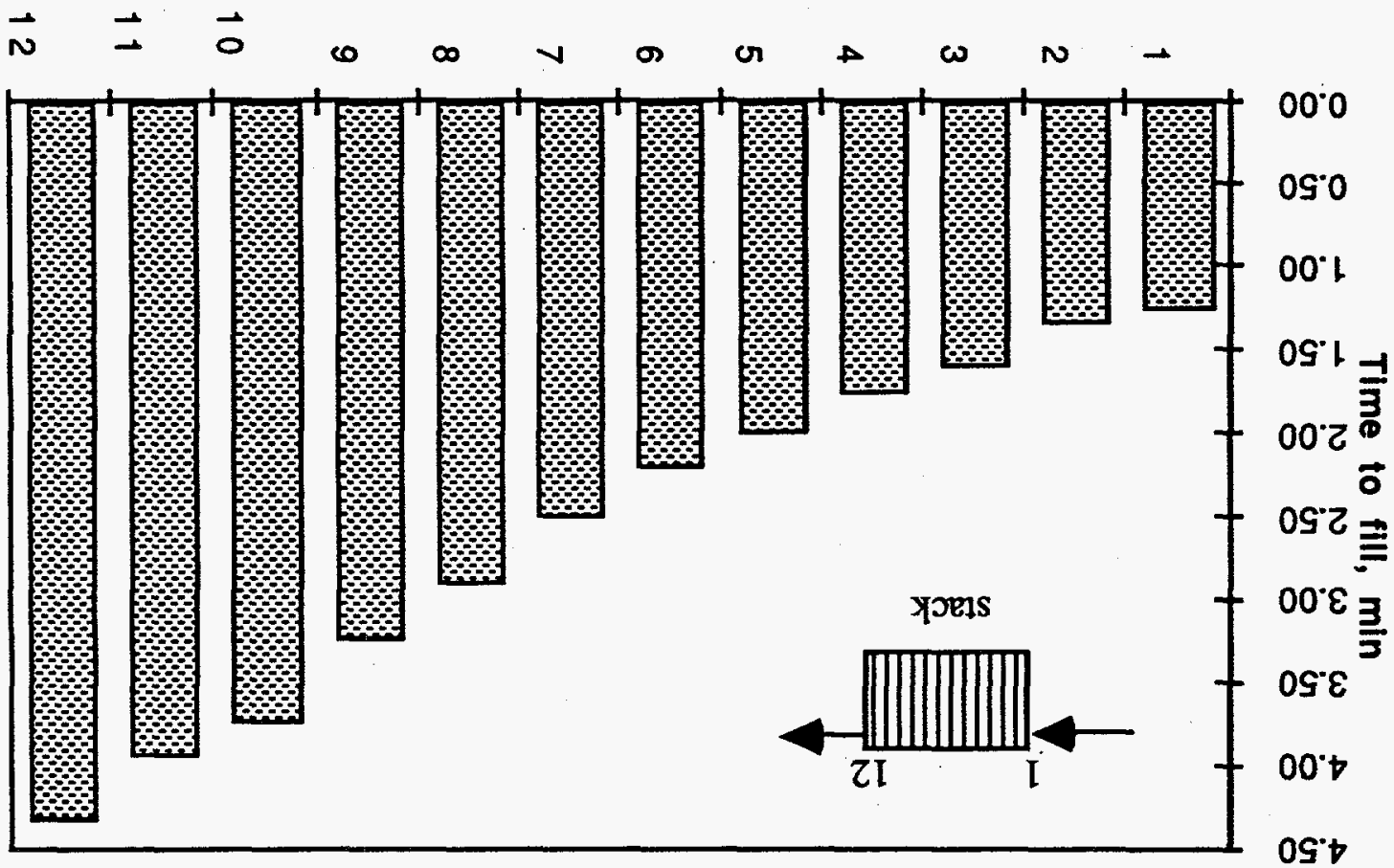

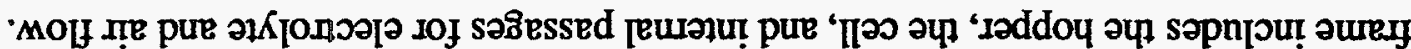

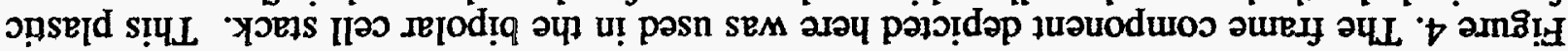

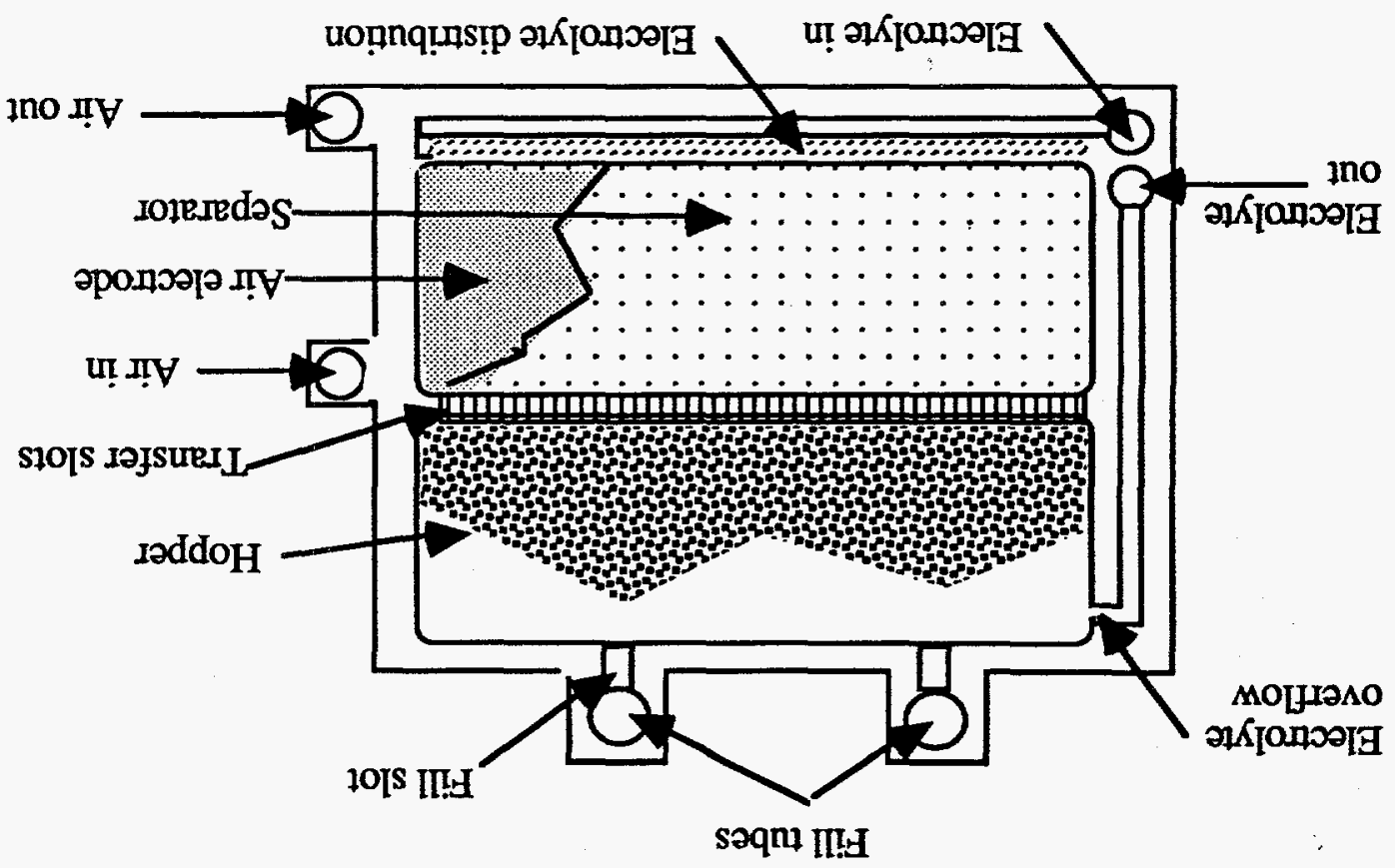


and wedge angle of this cell were reproduced in the $250-\mathrm{cm}^{2}$ cell used in laboratory refueling and in vehicle tests. After refueling tests on the twelve-cell stack, this stack was disassembled for tests in multiples of 1,3 , and 6 cells together with the same storage tank (sized for 12 cells) and auxiliaries.

The three cell stack was discharged for five hours then held on standby for 12 days, while the cells remained filled with cold, supersaturated electrolyte and the air flow was shut off. No deterioration in the polarization curves was noted following reactivation. This indicates that the strongly reducing potential of the oxygen-depleted zinc-filled cells does not cause deterioration of the separator or the air electrode catalyst.

The six cell stack (the largest discharged) was tested on board the electric bus, with the storage tank half filled with electrolyte. The power and voltage of the stack (averaged per cell) are plotted against current density in Figure 7. Superimposed are the voltage and power curves for the $80 \mathrm{~cm}^{2}$ cells (Figure 6). The difference in voltage and power density is attributed to the use of conductive silver-loaded epoxy resin cement to connect air electrodes to their substrates rather than the solder connection used in the smaller cells. The $10^{\circ} \mathrm{C}$ lower temperature of operation also lowered the power density because of the lower electrolyte conductivity.

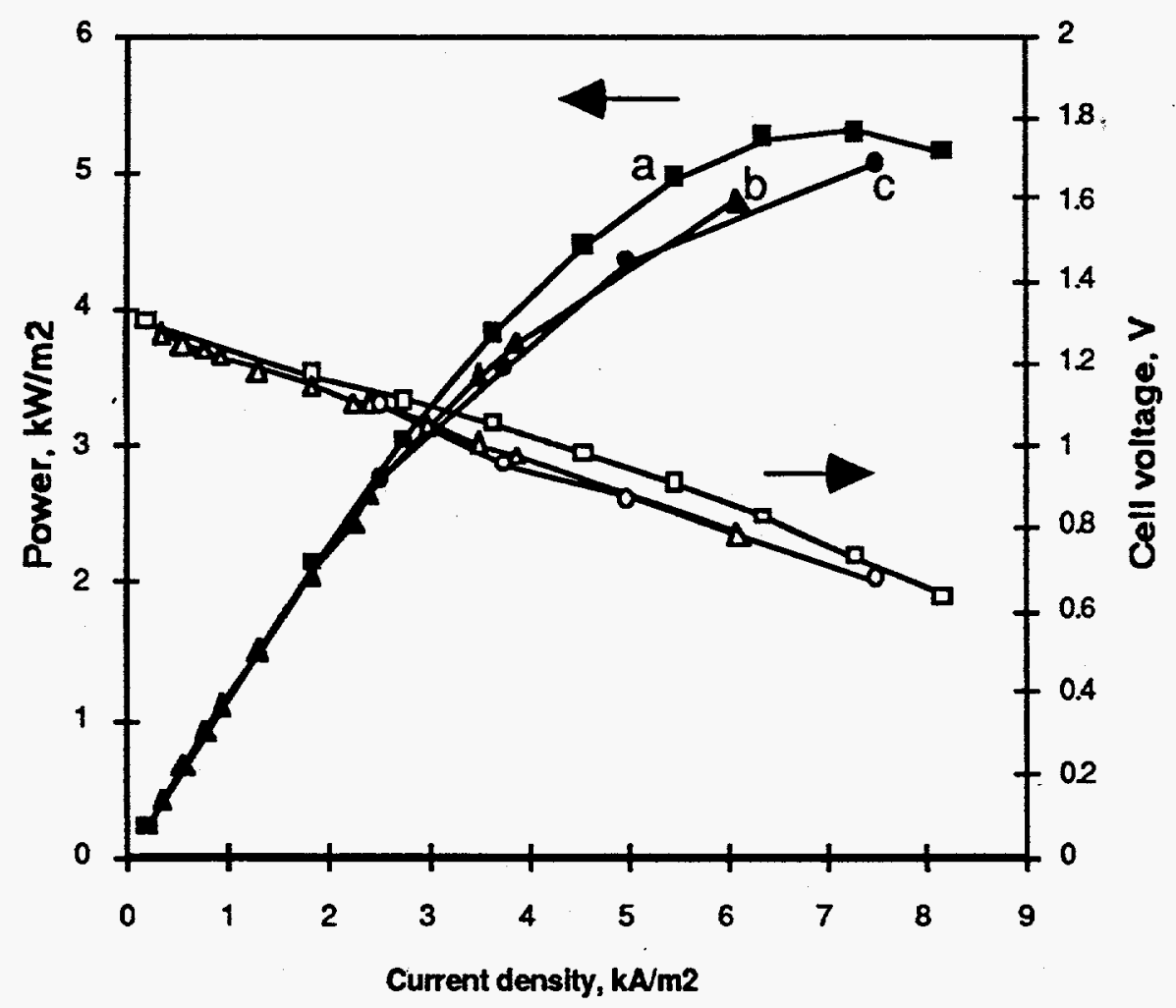

Figure 6. Power densities and voltages are given for discharge of the $80 \mathrm{~cm}^{2} \mathrm{cell}$ at a temperature of $65^{\circ} \mathrm{C}$. Curves are for three levels of electrolyte ampere-hour loading: (a) 36 Ah/liter; (b) $54 \mathrm{Ah} /$ liter; and (c) $126 \mathrm{Ah} /$ liter. The cell configuration and wedge angle were replicated in the $250 \mathrm{~cm}^{2}$ cells.

Vehicle Test Configuration and Results. On-vehicle tests were conducted in order to demonstrate the operation of the self-feeding cells under typical driving vibrations and accelerations, and to demonstrate a multicell level of system integration. The Santa Barbara Metropolitan Transit District (SBMTD) provided us with a 22 foot electric shuttle bus (Figure 9) for purposes of conducting this test. One 6-cell (7 V) battery was cabled in electrical parallel with a lead/acid battery consisting of three cells (6V; Chloride Motive Power, Ltd., Model 
S32Y11) to form the basic unit of a parallel-configured dual-battery hybrid power source. This unit was placed in series with 108 lead/acid cells of the same model (216 V) which normally provide all power. Both batteries in the hybrid unit were protected against reverse polarization with 300 A diodes. Current and voltage were monitored for each zinc/air cell, for the zinc/air stack, and for the drive train. A second on-board computer allowed measurement of power and total energy use with a 4-second time constant for the battery train. The bus was driven on a paved street around a 2 mile loop for 5 hours (including a 1 hour rest) until the lead/acid battery train was $80 \%$ discharged. Test conditions and salient results are reported in Table 1.

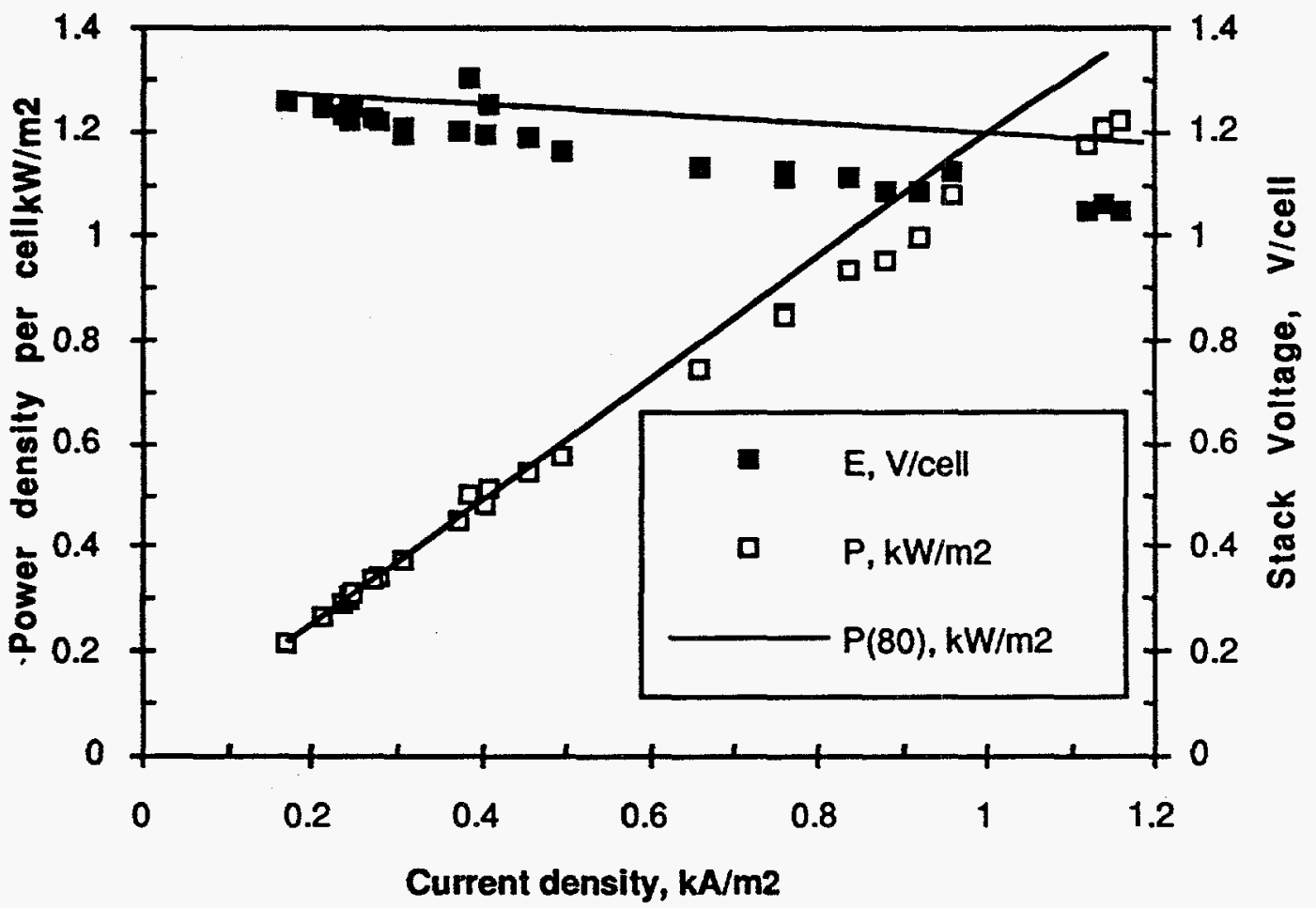

Figure 7. Cell voltage and power density (averaged per cell) are plotted against current density for the 6 cell stack at $55 \pm 1^{\circ} \mathrm{C}$. The power density and voltage curves from Figure 6 are superimposed. The difference reflects the lower temperature of operation and the use of a poorly conductive silver epoxy cement to bond the air electrode to its supporting conductor.

Table 2 tabulates the weights of the components and reactants used in the test. Energy yield is determined by the amount of consumable zinc with the electrolyte as the limiting reactant. The weights of the test cells are reported. One-half of the weight of the 12-cell tank was counted for this 6-cell test. Air pumps, scrubbers and motors will serve the entire vehicle battery array; accordingly, the value reported is based on available equipment pro-rated from $55 \mathrm{kWh}$ scale down to the 6-cell battery. A specific energy of $127 \mathrm{Wh} / \mathrm{kg}$ is indicated for the test equipment. The listing for production units $(141 \mathrm{Wh} / \mathrm{kg})$ is based on the same chemistry and configuration, but with $10 \%$ additional zinc and electrolyte. The production battery figure also assumes use of lightened cell frames constructed of filled polymers and transfer plates of 40 mil board with removal of unused cladding. We can fill the production cell hoppers to capacity and increase electrolyte and tank size accordingly, which leads to an energy density of $150 \mathrm{Wh} / \mathrm{kg}$. These differences will be seen to be insignificant for a bus battery, as this spread (127-150 Wh/kg) corresponds to about a $1 \%$ spread in resultant vehicle weights with the same range. 
Table 1. Test Conditions and Results for on-vehicle test of zinc/air in dualbattery hybrid power source

\begin{tabular}{|l|l|l|}
\hline Parameter & Value & Comments \\
\hline Bus test weight & $5700 \mathrm{~kg}$ & includes crew and test equip. \\
\hline Pb/acid drive battery weight & 2030 & $\begin{array}{l}108,2-V \text { Chloride Power cells } \\
\text { plus 3 cells parallel with 6-cell Zn/air }\end{array}$ \\
\hline Duration of test drive & $5.0 \mathrm{hours}$ & (includes $~-1$ hour rest; 75 stops) \\
\hline Distance driven & $120.7 \mathrm{~km}$ & \\
\hline Time-average speed & $24 \mathrm{~km} / \mathrm{h}$ & (average drive speed $\sim 30 \mathrm{~km} / \mathrm{h}$ ) \\
\hline Cycle length & $3.22 \mathrm{~km}$ & \\
\hline Total energy consumption & $35.748 \mathrm{kWh}$ & at battery terminals, including test unit \\
\hline Energy processed from test unit & $966 \mathrm{Wh}$ & at unit terminals \\
\hline Energy from zinc & $554 \mathrm{Wh}$ & at zinc/air terminals \\
\hline Energy from Pb and controls & $412 \mathrm{Wh}$ & incl. $\sim 12 \mathrm{Wh}$ dissipated in controls \\
\hline Fraction of energy from $\mathrm{Zn}$ & $57-58 \%$ & \\
\hline Initial charge of zinc battery & $3300 \mathrm{Wh}$ & Electrolyte is limiting reactant \\
\hline Depth of discharge of zinc & $17 \%$ & \\
\hline
\end{tabular}

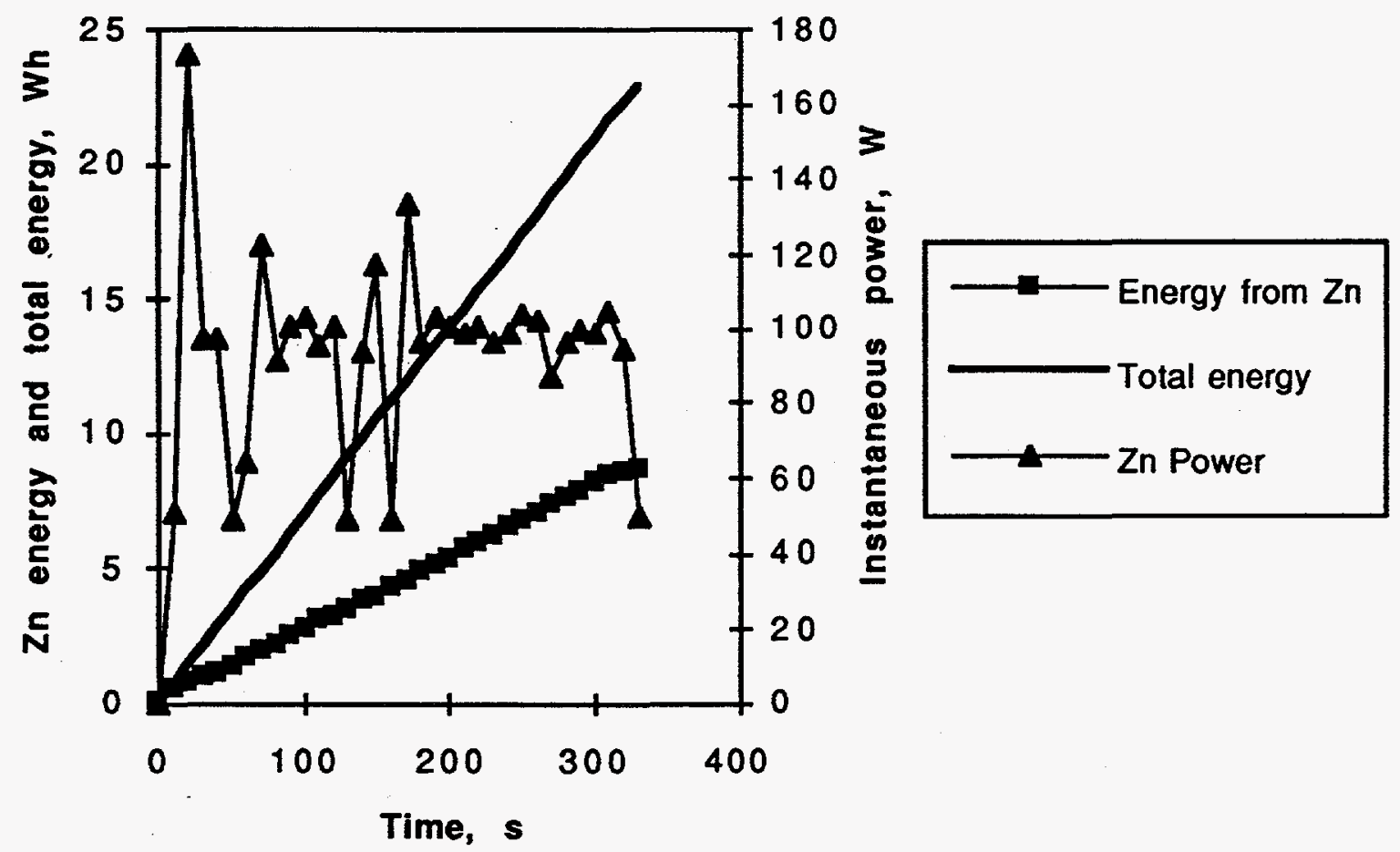

Figure 8. Instantaneous power, integrated power from zinc/air and time-averaged total energy from parallel unit is plotted against drive time for a $330 \mathrm{~s}, 3.22 \mathrm{~km}$ ( 2 mile) cycle. (Cycle No. 32 ). This part of the on-vehicle test was conducted at lower-than-optimum temperature of $42^{\circ} \mathrm{C}$.

While the peak rated power of the cells $(750 \mathrm{~W})$ and weight $(26 \mathrm{~kg})$ might suggest a low "specific power" of only $30 \mathrm{~W} / \mathrm{kg}$, such a conclusion would be misleading. The weight and volume of this kind of battery is dominated by the weight and volume of reactants and not by the weight and volume of the cells. Tripling the electrode area for the same tank and amount of reactants would triple the power to $2.25 \mathrm{~kW}$. However this increase would add $<3 \mathrm{~kg}$ (or 10\%) to weight to the battery -- an amount representing the additional electrodes and support (lower 
part of the cell, Figure 4). Unlike secondary and reconstructable zinc/air batteries, the energy and power of this battery are independent parameters and can be adjusted to meet the needs of the vehicle. Specific power has no unique meaning here, and cannot be used as a scale factor.

Rather, weight and volume can be estimated from the separate coefficients for peak power and nominal energy. The coefficients $2.8 \mathrm{~kg} / \mathrm{kW}$-peak and $6.5 \mathrm{~kg} / \mathrm{kWh}$-nominal can be derived from the "production" column in Table 2 . The corresponding volume coefficients are 3 $\mathrm{L} / \mathrm{kW}$-peak and $4 \mathrm{~L} / \mathrm{kWh}$-nominal. Thus the weight of a $27 \mathrm{~kW}$-peak battery delivering 46.8 $\mathrm{kWh}$ of energy at $80 \%$ DOD is $456 \mathrm{~kg}$ and occupies about $315 \mathrm{~L}\left(11 \mathrm{ft}^{3}\right)$. Because of the zinc reserve in each cell, the battery can be discharged to $100 \%$ DOD without harm.

Table 2. Battery component weights (6-cell stack and down-sized tank); Peak rated power, $750 \mathrm{~W}$.

\begin{tabular}{|l|c|c|c|}
\hline Component & $\begin{array}{c}\text { Test equipment } \\
\mathrm{kg}\end{array}$ & $\begin{array}{c}\text { Production units } \\
\mathrm{kg}\end{array}$ & $\begin{array}{c}\text { Projected units } \\
\mathrm{kg}\end{array}$ \\
\hline Cells, empty (6) & 2.8 & 1.7 & 1.5 \\
\hline Zinc (consumed fuel) & 3.3 & 3.6 & 4.8 \\
\hline Zinc (cell reserve) & 0.3 & 0.3 & 0.3 \\
\hline $\begin{array}{l}\text { Electrolyte: 250 AH/4 } \\
\text { set as limiting reactant }\end{array}$ & 15.2 & 16.5 & 22 \\
\hline Tank (1/2 of 12-cell) & 2.4 & 1.5 & 2.0 \\
\hline Auxiliaries & 2.0 & 2.0 & 1.5 \\
\hline Total weight & 26 & 25.6 & 32.1 \\
\hline Energy yield & $3300 \mathrm{Wh}$ & $3600 \mathrm{Wh}$ & $4800 \mathrm{Wh}$ \\
\hline Specific Energy & $127 \mathrm{Wh} / \mathrm{kg}$ & $141 \mathrm{Wh} / \mathrm{kg}$ & $150 \mathrm{Wh} / \mathrm{kg}$ \\
\hline
\end{tabular}

a Based on consumable zinc fuel; excludes undischarged zinc reserve of 8-10\% in cells.

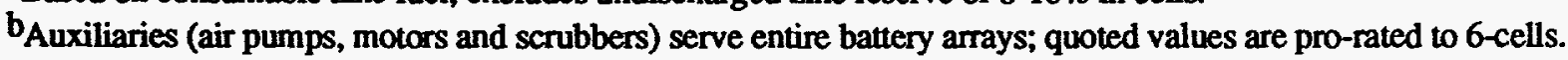

Table 3. Comparison of lead/acid and zinc/air (specific energy, $141 \mathrm{Wh} / \mathrm{kg}$ ) in shuttle bus on SBMTD urban duty cycle.

\begin{tabular}{|l|l|l|l|l|l|l|l|}
\hline Battery & $\begin{array}{l}\text { Test } \\
\text { weight } \\
\mathrm{kg} \mathrm{(b)}\end{array}$ & $\begin{array}{l}\text { Battery } \\
\text { weighta } \\
\mathrm{kg} \mathrm{(lb)}\end{array}$ & $\begin{array}{l}\text { Battery } \\
\text { volume, } \\
\mathrm{L}\left(\mathrm{ft}^{3}\right)\end{array}$ & $\begin{array}{l}\text { Required } \\
\text { energyb } \\
\mathrm{kWh}\end{array}$ & $\begin{array}{l}\text { Efficiency, } \\
\%\end{array}$ & $\begin{array}{l}\text { Energy } \\
\text { use } \\
\mathrm{kWh}\end{array}$ & $\begin{array}{l}\text { Range } \\
\mathrm{km}(\mathrm{mi})\end{array}$ \\
\hline $\begin{array}{l}\text { Lead/ } \\
\text { acid }\end{array}$ & $\begin{array}{l}5682 \\
(12,500)\end{array}$ & $\begin{array}{l}1977 \\
(4,350)\end{array}$ & $\begin{array}{l}794 \\
(28)\end{array}$ & 46.8 & 70 & 66.8 & $\begin{array}{l}116 \\
(72)\end{array}$ \\
\hline Zn/Air & $\begin{array}{l}4161 \\
(9,154)\end{array}$ & $\begin{array}{l}456 \\
(1,003)\end{array}$ & $\begin{array}{l}315 \\
(11)\end{array}$ & 46.8 & 60 & 78 & $\begin{array}{l}158 \\
(98)\end{array}$ \\
\hline Zn/Air & $\begin{array}{l}4052 \\
(8,914)\end{array}$ & $\begin{array}{l}347 \\
(763)\end{array}$ & $\begin{array}{l}248 \\
(9)\end{array}$ & 33.4 & 60 & 56 & $\begin{array}{l}116 \\
(72)\end{array}$ \\
\hline
\end{tabular}

aZinc/air weight is weight to deliver required energy at $80 \%$ exhaustion of consumable reactants from a battery of specific energy, $141 \mathrm{Wh} / \mathrm{kg}$.

behicle energy-use scale factor is $256 \mathrm{~kJ} /$ tonne-km (104 Wh/ton-mile) for the urban driving cycle.

In Table 3, we have calculated the weight and volume of the zinc/air battery that might be used on the SBMTD shuttle bus in its current duty cycle. Keeping either delivered energy constant (at $80 \%$ DOD) or the range constant, we have calculated reduced vehicle mass and total AC energy consumption using a vehicular specific energy consumption rate of $104 \mathrm{Wh} /$ ton-mile (SBMTD data, from the Santa Barbara Waterfront Route). Keeping range constant, the vehicle gross weight drops by $1600 \mathrm{~kg}$--equivalent to 20 passengers. Despite the lower energy efficiency of the zinc/air battery, total energy use is $20 \%$ lower than that of the lead/acid-powered bus because of the lower vehicle mass, all else being equal. The scaling of the zinc/air battery is 
based on the mass and volume coefficients of power and energy, with energy computed at $80 \%$ exhaustion of available energy. Tire and brake life and handling are also improved by weight reduction. The number of cells is fixed at $216(1.23 \mathrm{~V}$ nominal) and the peak rated power is 27 $\mathrm{kW}$. The power can be altered by altering the cell size or the number of cells.

\section{ECONOMY, ENERGY USE AND HYBRID CONFIGURATIONS}

Any detailed cost estimate is beyond the scope of this work. However, the $20 \%$ reduction in weight and energy use for fixed range and mission (passenger-miles) indicates a significant reduction of energy cost and tire and brake ware. The cost of zinc/air battery is dominated $(>50 \%)$ by the cost of the air electrode and its supporting structure, which we estimate to be $\$ 50 / \mathrm{kW}$-peak $+\$ 2 / \mathrm{kWh}$-capacity from a large-scale cathode production cost of $\$ 120 / \mathrm{m}^{2}$ (using continuous production techniques and cobalt macrocyclic catalysts).

The zinc battery described in Table 3 has sufficient power for the bus, giving the vehicle a power/weight ratio of $6.8 \mathrm{~W} / \mathrm{kg}$-gross (vs. the $5.2 \mathrm{~W} / \mathrm{kg}$-gross available with lead/acid). Nonetheless, consideration of a power leveled, parallel hybrid is encouraged for three reasons: (1) the power/weight ratio can be increased greatly, giving the vehicle greater route flexibility and highway-safe acceleration; (2) regenerative braking becomes possible, increasing efficiency by ca. $10 \%$; and (3) the life of the air electrode is maximized when current peaks are avoided. The electrodes used in this test operated without failure or serious deterioration for over 12,000 hours in a $7.5 \mathrm{M} \mathrm{KOH}+1 \mathrm{M}$ aluminate electrolyte at $60^{\circ} \mathrm{C}$ and $2 \mathrm{kA} / \mathrm{m}^{2}[8]$.

\section{CONCLUSIONS}

The essential objectives of this on-vehicle test were met. The self-feeding cells functioned correctly over the 5 hour test, without becoming clogged or starved. The refueling tests (on the 12 cell stack) showed filling rates of 4 cells/minute, which allows any number of parallel sets of 36 cells ( $19 \mathrm{kWh}$ per set) to be filled in parallel in 10 minutes. The battery functioned in a hybrid with the $6 \mathrm{~V}$ lead/acid pack, which was subjected to a rigid (high impedance) current source and a pulse-width modulated controller. The indicated specific energy (based on the electrolyte reactant limited to $250 \mathrm{Ah} / \mathrm{L}$ ) was $141 \mathrm{Wh} / \mathrm{kg}$, for laboratory test cells reduced to commercial production techniques. A disappointing feature of this work was the lower power obtained from the stack--the consequence of the use of conductive silver-epoxy rather than low-melting solder, cold bonding, or leaf metal bonding techniques used elsewhere for connecting air electrode screen substrates to conductors. Subsequent tests of the battery will correct this deficiency.

\section{Acknowledgments}

Work performed under the auspices of the U.S. Department of Energy by the Lawrence Livermore National Laboratory under contract number W-7405-ENG-48. We gratefully acknowledge the support of the Lawrence Livermore National Laboratory Institutional Research and Development Program in the initial phases of this work. We gratefully acknowledge the support for this project by the Department of Transportation (Federal Transit Administration) through its contractor, CALSTART, INC. (Burbank, CA). Finally we express our gratitude to the Santa Barbara Metropolitan Transit District for allowing us to use the Electric Shuttle Bus in this research.

\section{REFERENCES}

1. John F. Cooper, Dennis Fleming, Ronald Koopman, Douglas Hargrove, Arturo Maimoni and Keith Peterman, "Testing of a refuelable zinc/air bus battery," Proc. of the Electrochemical Society, May 21, 1995; LLNL Report UCRL-JC-119686 December 1994. 
2. Jonathan R. Goldstein and Binyamin Koretz, "Tests of a full-sized mechanically rechargeable zinc-air battery in an electric vehicle," Proc. Intersociety Energy Conversion Engineering Conference, Paper No. 93410, Atlanta Georgia, August 1993.

3. Evans, J. W. and Savaskan, "A zinc-air cell employing a packed bed anode," J. Appl. Electrochem., 21, 105-110 (1991)

4. Sierra Alcazar H. B., Nguyen P. D. and Pinoli, A. A., Technology Base Research on Zinc/Air Battery Systems, LBL-Report No. 23960, September 1987.

5. Appleby, J. and M. Jacquier The C. G. E. Circulating Zinc/Air Battery, J. Power Sources vol. 1, pp. 17-34 (1976/77)

6. John F. Cooper, Dennis Fleming, Larry Keene, Arturo Maimoni, Keith Peterman and Ronald Koopman, "Preliminary Results in the Refueling of a Multicell Module," (Paper No. AIAA - 94- 3841; Proc. 29th Intersociety Energy Conversion Engineering Conference; Monterey, CA August 7-12, 1994; LLNL Report No. UCRL JC 117946, August 1994.

7. John F. Cooper, Larry Keene, Jon Noring, Arturo Maimoni and Keith Peterman, "Regenerative Zinc/Air and Zinc/Ferricyanide Batteries for Stationary Power Applications," Proc. 36 Power Sources Conference, Cherry Hill, NJ, June 6-9 1994; LLNL Report UCRL-117248-Rev. 1, May 1994.

8. The separator was a perforated polymer membrane manufactured by Pall RAI Manufacturing Company, Inc.; Hauppauge, NY.

9. Air electrodes were manufactured by Eltech Research Company, Painesville OH; Model AE100 catalyzed with cobalt tetramethoxy-phenyl-porphyrin (Co TMPP). Life data from private communication from Dr. Eric Rudd, Eltech Research Company, May 1993.

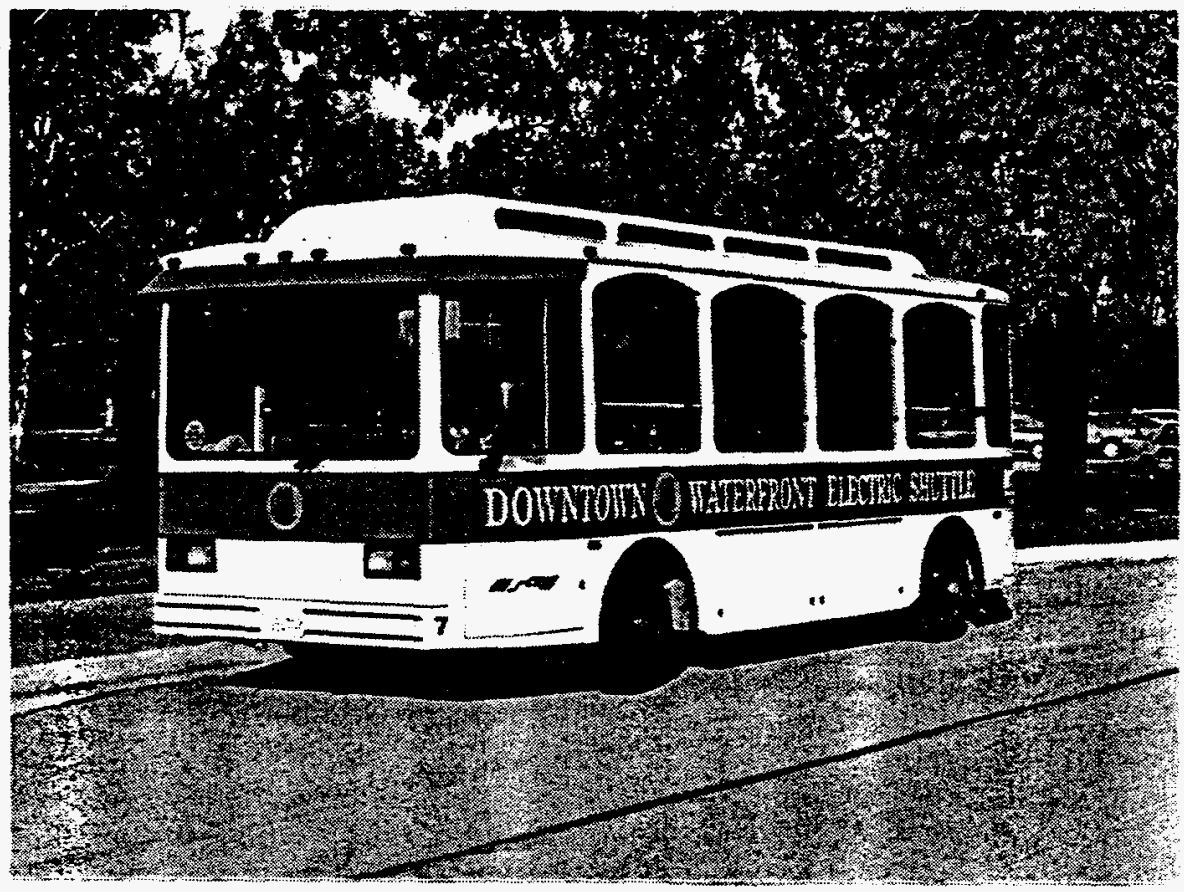

Figure 9. Shown is the electric shuttle bus used in testing the 6-cell stack (loaned to us by the Santa Barbara Metropolitan Transit District, a CALSTART, Inc. affiliate). 